matory conditions such as thrombophlebitis. Objective evidence of the beneficial effects of such treatment, however, has hitherto been lacking.

In our trial, the radioactivity disappeared significantly more rapidly from the site of the thrombophlebitis in the heparinoidtreated patients than in those treated with the placebo $(\mathrm{P}<0.001)$. Furthermore, the disappearance or persistence of local symptoms and signs of thrombophlebitis closely followed the decline or increase in radioactivity.

When ${ }^{125} \mathrm{I}$-labelled fibrinogen is injected intravenously it is incorporated into a forming thrombus. Repeated counts of radioactivity over the site of the thrombus and over areas where there are no thrombi allow a quantitative assessment of the fate of the thrombus. ${ }^{7}$ The decrease in the percentage difference of radioactivity over these two sites indicates the rate of thrombus dissolution; this has been confirmed by repeated phlebography. It is therefore reasonable to suggest that the rapid decline in radioactivity observed in the patients treated with the heparinoid cream probably represented lysis of thrombi and disappearance of radioactive fibrin/fibrinogen from locally accumulated inflammatory exudate.

A drawback of this trial was that it did not provide clear evidence of the true extent of thrombolysis and the nature of residual intimal damage. Phlebography before and after treatment was not performed because of the risk that injection of contrast medium might produce further damage to the already inflamed intima and thus induce extension of the thrombotic process. Another objective method would have been to remove a small segment of affected vein under local anaesthesia and study it histologically to assess residual thrombus and intimal damage; such investigations were, however, considered unethical.
In view of the clear evidence of symptomatic relief and objective evidence of rapid decline in local radioactivity it is hard to deny that the beneficial effects observed in patients receiving heparinoid ointment were due to the drug itself.

We thank the consultant surgeons of King's College Hospital for allowing us to study their patients, the nursing staff for their invaluable help, the King's College Hospital Research Trust for financial support, Luitpold-Werk (Munich) for supplies of Hirudoid and placebo cream, and Mr. D. Taylor for technical work. We also thank Mrs. M. G. Shelton for secretarial help.

Requests for reprints should be addressed to: Mr. V. V. Kakkar, Department of Surgery, King's College Hospital Medical School, Denmark Hill, London SE5 8RX.

\section{References}

${ }^{1}$ Medical Research Council, Lancet, 1957, 1, 595.

2 Vere, D. W., Sykes, C. H., and Armitage, P., Lancet, 1960, 2, 627.

${ }^{3}$ McNair, T. J., and Dudley, H. A. F., Lancet, 1959, 2, 365.

4 Brunner, O., Gynaecologia, 1954, 138, 13.

5 Dieckman, C., Medizinische Klinik, 1951, 46, 798.

6 Tronnier, H., Economou, G., and Hebert, U. M., Medizinische Welt, $1967,2,3179$.

${ }^{7}$ Kakkar, V. V., et al., British Fournal of Surgery, 1969, 56, 178.

${ }^{8}$ Kakkar, V. V., et al., Lancet, 1970, 1, 540.

9 Brown, G. A., British Fournal of Clinical Practice, 1970, 24, 197.

10 Buchtela, K., Arzneimittel-Forschung, 1967, 17, 591.

11 Hästbacka, J., and Tammisto, T., Nordisk Medicin, 1967, 77, 444.

12 Lipecz, J., and Bihler, K., Medizinische Welt, 1969, 2, 1662.

13 Schmidt, G., Hippokrates, 1960, 31, 699.

14 Walther, C., Koestering, H., and Cordes, V., Arzneimittel-Forschung, $1969,19,75$

15 Rantakallio, P., Juntunen, K., and Kauste, Olli, Annales Paediatriae Fenriae, 1965, 11, 186.

\title{
Reassessment of Failed Beta-blocker Treatment in Angina Pectoris by Peak-exercise Heart Rate Measurements
}

\author{
GRAHAM JACKSON, LYNNE ATKINSON, SAMUEL ORAM
}

British Medical fournal, 1975, 3, 616-618

\section{Summary}

Twenty-one patients with angina pectoris were treated with adrenergic beta-receptor antagonists. Previously the resting heart rate had been used as a guide to treatment, a reduction in the rate to $55-60$ beats/min without symptomatic improvement indicating failure of medical treatment. These patients were re-evaluated before coronary arteriography using the peak-exercise heart rate as an index of adrenergic beta-receptor antagonism. The dose of beta-blocking drugs was increased to produce a peak-exercise heart rate of less than 100 beats/min or a consistent rate of $100-125$ beats/min which would not

Cardiac Department, King's College Hospital, London SE5 9RS GRAHAM JACKSON, M.B., M.R.C.P., Lecturer in Cardiology LYNNE ATKINSON, B.SC., Research Assistant

SAMUEL ORAM, M.D., F.R.C.P., Director lessen in spite of progressive dose increments. The resting heart rate was ignored. On these criteria 15 patients previously considered to have responded inadequately to beta-blockade responded satisfactorily and were therefore removed from the waiting list for coronary arteriography. They all remained well up to two years later. Six patients failed to respond and had coronary arteriography with a view to surgical treatment. Reliance on the resting heart rate as the index of optimum adrenergic beta-receptor antagonism is likely to lead to premature or unnecessary referral for surgery; the failure of beta-blockade in the treatment of angina pectoris can be determined simply and accurately by using peak-exercise heart rate.

\section{Introduction}

Adrenergic beta-receptor antagonists are well established in the treatment of both stable and unstable angina pectoris. ${ }^{12}$ In patients with angina pectoris the expected yearly mortality rate with medical treatment is about $4 \%,{ }^{3}$ but this does not take account of long-term adrenergic beta-receptor antagonism as a 
form of treatment. No satisfactory data are available on the long-term mortality of patients with angina pectoris treated with adrenergic beta-receptor antagonists, but the incidence of sudden death was reduced after myocardial infarction in patients treated with alprenolol. ${ }^{4}$ Surgery is often effective in relieving anginal pain but it is not yet clear whether the patient's longterm prognosis will be improved until prospective randomized studies comparing surgical and medical treatment are completed. In the most experienced cardiac centres the mortality rate for coronary arteriography may be as low as $0 \cdot 1 \%,{ }^{5}$ but this figure may exceed $2 \%{ }^{6}$ Clear indications for coronary arteriography are therefore mandatory. The immediate hospital mortality rate for coronary arterial surgery is about $5 \%$ in experienced centres, ${ }^{78}$ but may be greater in others. The long-term survival after surgical treatment is not clearly documented but may reflect the basic disease process, atherosclerosis, which has, of course, not been treated. The main criterion for consideration for coronary arteriography with a view to coronary arterial surgery is the failure of medical treatment to relieve anginal pain. ${ }^{79}$

A test used in clinical practice to assess the degree of adrenergic beta-receptor antagonism relies empirically on the reduction of the resting heart rate to $55-60$ beats/min. ${ }^{1011}$ This criterion takes no account of the lower resting heart rates achieved with propranolol in comparison with either adrenergic beta-receptor antagonists with cardioselective properties ${ }^{12}$ or antagonists with intrinsic sympathomimetic activity. ${ }^{13}$ Furthermore, anti-anginal treatment is based largely on the reduction of myocardial oxygen consumption by the reduction of exertional heart rate, and though a correlation may exist between resting and exercise heart rates this varies with different adrenergic beta-receptor antagonists. ${ }^{14} 15$

Because the resting heart rate was being used as the criterion of optimum beta-receptor antagonism we suspected that some patients were being investigated as candidates for surgical treatment before optimum medical treatment had been reached. We therefore re-evaluated patients awaiting coronary arteriography by using peak-exercise heart rates after a maximal exercise test, and we describe here the therapeutic outcome.

\section{Patients and Methods}

Twenty-one patients less than 65 years of age with angina pectoris were seen at the Brook General Hospital and King's College Hospital. Because adrenergic beta-receptor antagonist treatment produced a resting heart rate of 55-60 beats/min and symptomatic improvement remained unsatisfactory they had been placed on the waiting list for coronary arteriography.

After a detailed case history had been taken the patients were carefully examined and they were then seen every fortnight. There was no evidence of anaemia (haemoglobin $<13 \mathrm{~g} / \mathrm{dl}$ ), cardiac failure, obstructive airways disease, cardiac infarction in the previous three months, diabetes, or thyroid disease. Chest $x$-ray pictures were normal. All previous drug treatment was discontinued other than glyceryl trinitrate, which was not used preventively. The patients received on a random basis either tolamolol or propranolol. Tolamolol was increased at fortnightly intervals in increments of $100 \mathrm{mg}$ thrice daily. As all patients had previously been on propranolol the first dose was $80 \mathrm{mg}$ thrice daily and subsequent fortnightly increments were $80 \mathrm{mg}$ thrice daily. They were exercised at each visit under standard conditions, ${ }^{16}$ using the large muscle-mass exercise test of Kaltenbach, ${ }^{17}$ as modified and described by Livesley. ${ }^{18}$ Patients exercised until they experienced the onset of anginal pain or were too breathless to continue. Radiotelemetry with the electrode in the V5 position was used to record resting and exercise heart rates from the electrocardiogram. The object was to achieve a peak-exercise heart rate of less than 100 beats/min by repeatedly increasing the dose or, if this figure could not be reached, consistent heart rates of 100-125 beats/min. All observations were made on the same day of the week and so far as possible at the same time of day.

Depression of the $S-T$ segment was measured during and after peak exercise. A downward-sloping depression of at least $1 \mathrm{~mm}$ persisting for 0.08 seconds or longer in at least five consecutive beats was considered indicative of ischaemia. Patients recorded their anginal attack rate and glyceryl trinitrate consumption on special cards.

If a patient improved clinically on subjective criteria the dose was not increased-for example, only five patients on propranolol needed more than $80 \mathrm{mg}$ thrice daily-and the patient was withdrawn from the waiting list for coronary arteriography and treated medically. If he failed to improve as a result of increasing the dose of propranolol or tolamolol such that the peak-exercise heart rate satisfied the above criteria coronary arteriography was performed.

\section{Results}

Details of individual patients are shown in table I and mean observations in table II. For statistical analysis we used Tukey's test, Friedman's two-way analyses of variance, a parametric analysis of variance, and Cochran's $Q$ test.

TABLE I-Resting and Exercise Heart Rates (beats/min) on Two Doses of Each Drug in Patients taking Tolamolol or Propranolol

\begin{tabular}{|c|c|c|c|c|c|c|}
\hline \multirow[t]{2}{*}{$\begin{array}{l}\text { Case } \\
\text { No. }\end{array}$} & \multicolumn{2}{|c|}{ No Treatment } & \multicolumn{2}{|c|}{$\begin{array}{l}\text { Tolamolol, } 100 \mathrm{mg} \text { t.d.s. } \\
\text { Propranolol, } 80 \mathrm{mg} \text { t.d.s. }\end{array}$} & \multicolumn{2}{|c|}{$\begin{array}{l}\text { Tolamolol, } 200 \mathrm{mg} \text { t.d.s. } \\
\text { Propranolol, } 160 \mathrm{mg} \text { t.d.s. }\end{array}$} \\
\hline & Rest & Exercise & Rest & Exercise & Rest & Exercise \\
\hline \multicolumn{7}{|c|}{ Patients on Tolamolol } \\
\hline $\begin{array}{r}1 \\
2 \\
3 \\
4 \\
5 \\
6 \\
7 \\
8 \\
9 \\
10\end{array}$ & $\begin{array}{r}86 \\
64 \\
65 \\
71 \\
88 \\
72 \\
76 \\
59 \\
88 \\
106\end{array}$ & $\begin{array}{l}140 \\
145 \\
140 \\
130 \\
150 \\
140 \\
130 \\
102 \\
170 \\
155\end{array}$ & $\begin{array}{l}53 \\
70 \\
41 \\
82 \\
54 \\
58 \\
55 \\
\\
66 \\
75\end{array}$ & $\begin{array}{l}120 \\
125 \\
110 \\
150 \\
105 \\
108 \\
102 \\
110 \\
115\end{array}$ & $\begin{array}{l}62 \\
68 \\
53 \\
67 \\
73 \\
69 \\
70 \\
50 \\
72 \\
64\end{array}$ & $\begin{array}{r}94 \\
95 \\
75 \\
105 \\
98 \\
100 \\
98 \\
82 \\
110 \\
110\end{array}$ \\
\hline \multicolumn{7}{|c|}{ Patients on Propranolol } \\
\hline $\begin{array}{l}11 \\
12 \\
13 \\
14 \\
15 \\
16 \\
17 \\
18 \\
19 \\
20 \\
21\end{array}$ & $\begin{array}{r}80 \\
59 \\
85 \\
86 \\
80 \\
88 \\
110 \\
85 \\
96 \\
88 \\
75\end{array}$ & $\begin{array}{l}150 \\
130 \\
140 \\
140 \\
120 \\
150 \\
140 \\
112 \\
150 \\
155 \\
130\end{array}$ & $\begin{array}{l}48 \\
43 \\
75 \\
55 \\
70 \\
59 \\
70 \\
62 \\
57 \\
76 \\
62\end{array}$ & $\begin{array}{r}86 \\
100 \\
120 \\
92 \\
104 \\
100 \\
100 \\
90 \\
110 \\
125 \\
105\end{array}$ & $\begin{array}{l}57 \\
73 \\
64\end{array}$ & 112 \\
\hline
\end{tabular}

Heart Rates.-In the assessment of angina pectoris each patient's observations must be judged individually. While mean observations are interesting statistically and show trends to be expected in management they have little influence on the care of a particular patient. Often the resting heart rate on tolamolol $100 \mathrm{mg}$ thrice daily was below the criterion of 55 beats/min, whereas the exercise heart rate was consistently above 100 beats $/ \mathrm{min}$. Increasing the dose to $200 \mathrm{mg}$ thrice daily was associated in some cases with an increase in resting heart rate, but there was an invariable reduction in peak-exercise

\begin{tabular}{|c|c|c|c|c|c|c|c|c|}
\hline & & & \multirow{2}{*}{$\begin{array}{l}\text { Control for } \\
\text { Tolamolol }\end{array}$} & \multicolumn{2}{|c|}{ Tolamolol } & \multirow{2}{*}{$\begin{array}{l}\text { Control for } \\
\text { Propranolol }\end{array}$} & \multicolumn{2}{|c|}{ Propranolol } \\
\hline & & & & $100 \mathrm{mg}$ t.d.s. & $200 \mathrm{mg}$ t.d.s. & & $80 \mathrm{mg}$ t.d.s. & $160 \mathrm{mg}$ t.d.s \\
\hline $\begin{array}{l}\text { Weekly anginal attack rate.. } \\
\text { Heart rate/min: }\end{array}$ & $\cdots$ & $\cdots$ & $8 \cdot 6 \pm 2 \cdot 2$ & $7 \cdot 2 \pm 2 \cdot 5$ & $3 \cdot 3 \pm 0 \cdot 5$ & $15 \pm 3 \cdot 8$ & $10 \cdot 8 \pm 4 \cdot 7$ & $1 \cdot 7 \pm 0 \cdot 9$ \\
\hline 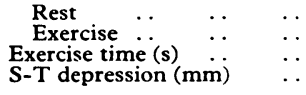 & $\begin{array}{l}\cdots \\
\cdots \\
\cdots\end{array}$ & $\begin{array}{l}\cdots \\
\cdots \\
\cdots\end{array}$ & $\begin{array}{c}77 \cdot 5 \pm 4 \cdot 6 \\
140 \cdot 2 \pm 5 \cdot 7 \\
94 \cdot 7 \pm 10 \cdot 1 \\
1 \cdot 8 \pm 0 \cdot 5\end{array}$ & $\begin{array}{c}61 \cdot 6 \pm 4 \cdot 2 \\
116 \cdot 1 \pm 4 \cdot 9 \\
126 \cdot 3 \pm 13 \cdot 4 \\
1 \cdot 2 \pm 0 \cdot 6\end{array}$ & $\begin{array}{c}64 \cdot 8 \pm 25 \\
96 \cdot 7 \pm 3 \cdot 6 \\
125 \cdot 2 \pm 13 \cdot 2 \\
0 \cdot 6 \pm 0 \cdot 3\end{array}$ & $\begin{aligned} 84 \cdot 7 & \pm 3 \cdot 8 \\
128 \cdot 8 & \pm 8 \cdot 8 \\
94 \cdot 9 & =11 \cdot 0 \\
1 \cdot 3 & \pm 0 \cdot 3\end{aligned}$ & $\begin{array}{r}61 \cdot 6 \pm 3 \cdot 2 \\
102 \cdot 9 \pm 3 \cdot 6 \\
118 \cdot 8 \pm 8 \cdot 0 \\
0 \cdot 5 \pm 0 \cdot 2\end{array}$ & $\begin{aligned} 69 & \pm 5 \cdot 4 \\
106 \cdot 8 & \pm 4 \cdot 0 \\
129 \cdot 3 & \pm 20 \cdot 5 \\
0 \cdot 25 & \pm 0 \cdot 25\end{aligned}$ \\
\hline
\end{tabular}


heart rate, which showed the inaccuracy of assessments based on resting heart rate alone. In patients treated with propranolol $80 \mathrm{mg}$ thrice daily two patients with resting heart rates of 43 and 48 beats/ min were successfully treated on this dose since their peak-exercise heart rate was reduced to 100 beats/min or less. On propranolol $160 \mathrm{mg}$ thrice daily the resting heart rates in cases, 1319,20 , and 21 varied only slightly from those on $80 \mathrm{mg}$ thrice daily but the peak-exercise heart rates were significantly reduced, and the increased dose was associated with clinical improvement. Though the patient in case 20 received increments of propranolol to $320 \mathrm{mg}$ thrice daily this dose produced no clinical improvement or reduction in peak-exercise heart rate over that produced by $160 \mathrm{mg}$ thrice daily.

The mean heart rates at rest were reduced on both drugs when compared with control $(P<0.01)$, but the resting heart rates on the higher dose of each drug did not differ from those on the lower dose. The exercise heart rate was reduced in nearly all cases on the higher dose of each drug as compared with the lower dose $(P<0.05)$.

Exercise Tolerance.-This was increased in all but one patient after receiving the first dose of each drug $(P<0.05)$. In four patients an increased dose resulted in reduced exercise time but in only one of these was there no further subjective benefit (case 2). There was no obvious explanation for this, though the increased dose in some patients might be associated with less anginal pain but more exertional breathlessness, possibly owing to early left ventricular failure.

Electrocardiographic Changes.-Both drugs consistently reduced the degree of depression of the S-T segment induced by exercise. A reduction in the amount of S-T segment depression was associated with an increase in exercise time in 11 cases and with a reduction in exercise time in two cases. In eight patients the $S-T$ segment was unchanged. In two of the six patients referred for surgical treatment the depression of the S-T segment was reduced.

Anginal Attack Rates. - These were reduced in all patients except those referred for surgical treatment. There was no significant relation between the frequency of anginal attacks, the degree of S-T segment depression, and exercise tolerance.

Therapeutic Outcome.-Fifteen patients previously considered to have received maximum benefit from adrenergic beta-receptor antagonists showed further improvement when we used the peakexercise heart rate as a guide to treatment. They were leading active lives and remained well up to two years later. Six patients were referred for consideration for surgical treatment. Three (cases 8, 9, and 15) were accepted for operation, all having occlusions greater than $50 \%$ in the three major coronary arteries; one (case 18) refused operation and remained alive but restricted two years later; and two (cases 16 and 20) had severe triple vessel disease and were considered inoperable. One of the inoperable patients (case 16) died from further cardiac infarction while the other (case 20) improved and, at the time of writing, was leading an active life on propranolol $160 \mathrm{mg}$ thrice daily.

\section{Discussion}

Angina pectoris occurs when myocardial energy demand exceeds supply. The energy requirement rises in an almost linear relation with the rise in heart rate. ${ }^{19}$ On exertion the increase in heart rate at low work levels is due principally to the withdrawal of vagal inhibition. ${ }^{20}$ To assess the effect of the sympathetic nervous system on the heart rate it is necessary to perform a strenuous exercise test. ${ }^{21}$ After thoracic sympathectomy and $80 \mathrm{mg}$ of oral propranolol peak-exercise heart rates in healthy people were 100-125 (mean 113) beats $/ \mathrm{min} .{ }^{20}$ An optimum reduction in sympathetic drive may therefore be assumed if the peak-exercise heart rate is less than 100 beats $/ \mathrm{min}$ or in the range $100-125$ beats $/ \mathrm{min}$ and is not reduced by increasing further the dose of adrenergic beta-receptor antagonists.

The application of this physiological concept to the assessment of adrenergic beta-receptor antagonism is important because of our lack of knowledge of the long-term effects of coronary arterial surgery. Though resting heart rates are taken by many people as an index of beta-adrenergic blockade this is mistaken. By disregarding the resting heart rate down to a level of 35-40 beats/min we achieved good medical control of anginal pain in 15 patients, all of whom were leading active lives up to two years later. Six patients failed to respond. We have established that an individual's resting heart rate has no predictive value with regard to exercise tolerance, symptomatic improvement, or the degree of adrenergic beta-receptor antagonism. There seems to be no relation between frequency of anginal attacks, reduction in S-T segment depression, and exercise tolerance. In our view the peak-exercise heart rate is the only reliable clinical indicator of the degree of adrenergic beta-receptor antagonism and, in turn, symptomatic improvement.

In clinical practice when patients benefit from anti-anginal treatment only routine investigations are indicated. When failure of treatment with beta-blockers is suspected, however, a strenuous exercise test offers a simple physiological assessment of adequate treatment which may prevent premature and unnecessary referral for surgical treatment. The reason for the exercise test was explained to each patient and their consent was obtained. We have now performed over 1000 exercise tests in two years with no morbidity or mortality. Nevertheless, no exercise tests should be performed unless strict precautions are taken under hospital conditions, ${ }^{19}$ such as are readily available at centres performing coronary arteriography.

In conclusion, we suggest the following plan of assessment before accepting that beta-blocker treatment has failed. A strenuous exercise test should be used to establish whether optimum adrenergic beta-receptor antagonism has been achieved. If the peak-exercise heart rate is over 100 beats/min an increased dose should be given in an attempt to reduce the peak-exercise heart rate to less than 100 beats/min. Further symptomatic improvement may then result. Failure of beta-blocker treatment may be assumed if the patient remains disabled and the peakexercise heart rate is less than 100 beats/min or remains in the 100-125 beats/min range and will not lessen in spite of an increase in beta-blocker dose. If successive drug increments produce similar peak heart rates but on the higher dose the patient's exercise time is reduced or his end-point changes from pain to breathlessness then the possibility of excessive adrenergic beta-receptor antagonism must be considered and early left ventricular failure excluded.

We thank Dr. Douglas Chamberlain, who gave invaluable advice; Drs. Ronald Hartley and Max Zoob, who kindly referred patients to us; Dr. Richard Walden, who organized supplies of tolamolol ; and Mr. Michael Clarke for his statistical help. This project was supported by a Pfizer research grant.

\section{References}

1 Gillam, P. M. S., and Prichard, B. N. C., British Medical Fournal, 1965, $2,337$.

2 Master, A. M., and Jaffe, H. L., American Heart Fournal, 1974, 87, 321

3 Kannel, W. B., and Feinleib, M., American fournal of Cardiology, 1972, 29, 154.

4 Wilhelmsson, C., et al., Lancet, 1974, 2, 1157.

5 Adams, D. F., Fraser, D. B., and Abrams, H. L., Circulation, 1973, 48, 609.

6 Emmanuel, R., British Heart fournal, 1975, 37, 229.

7 Kouchoukos, N. T., Kirklin, J. W., and Oberman, A., Circulation, 1974, 50,11 ,

${ }^{8}$ Gott, V. L., American fournal of Cardiology, 1974, 33, 431.

${ }^{9}$ Aronow, W. S., and Stemmer, E. A., American fournal of Cardiology, $1974,33,415$.

10 Prichard, B. N. C., Lionel, N. D. W., and Richardson, G. A., Postgraduate Medical fournal, 1971, 47, Suppl. (Jan.), p. 59.

11 Logue, R. B., and Robinson, P. H., Circulation, 1972, 46, 1132

12 Barrett, A. M., Postgraduate Medical fournal, 1971, 47, Suppl. (Jan.), p. 7.

${ }^{13}$ Hill, R. C., and Turner, P., British Fournal of Pharmacology, 1969, 36, 368.

14 Thadani, U., ot al., British Medical fournal, 1973, 1, 138

15 Sowton, E., Das Gupta, D. S., and Baker, I., Thorax, 1975, 30, 9.

16 Jackson, G., Atkinson, L., and Oram, S., British Medical fournal, 1975, 1, 708.

1: Kaltenbach, M., Beurteilung der Leistungereserven von Herzkranken mit Hilfe von Stufenbelastungen. Mannheim, Boehringer, 1968.

18 Livesley, B., et al., British Medical fournal, 1973, 1, 375.

19 Andersen, K. L., et al., Fundamentals of Exercise Testing. Geneva, World Health Organization, 1971.

20 Chamberlain, D. A., M.D. Thesis, University of Cambridge, 1967

${ }_{21}$ Shanks, R. G., Irish fournal of Medical Science, 1970, 3, 247. 